\title{
Curcumin and epithelial-mesenchymal transition in breast cancer cells transformed by low doses of radiation and estrogen
}

\author{
MARCELA GALLARDO $^{1}$ and GLORIA M. CALAF ${ }^{1,2}$ \\ ${ }^{1}$ Instituto de Alta Investigación, Universidad de Tarapacá, Arica 8097877, Chile; \\ ${ }^{2}$ Center for Radiological Research, Columbia University Medical Center, New York, NY 10032, USA
}

Received January 14, 2016; Accepted February 20, 2016

DOI: $10.3892 /$ ijo.2016.3477

\begin{abstract}
Breast cancer is a major cause of global mortality in women. Curcumin exerts anti-proliferative, anti-migratory and apoptotic effects. The aim of this study was to evaluate gene expression involved in epithelial-mesenchymal transition (EMT). An in vitro model was developed with the MCF-10F immortalized breast epithelial cell line exposed to low radiation doses of high LET (linear energy transfer) $\alpha$-particles $(150 \mathrm{keV} / \mu \mathrm{m})$ and cultured in the presence of $17 \beta$-estradiol (estrogen). The following cell lines were used: i) MCF-10F, normal; ii) Alpha5, pre-tumorigenic, and iii) Tumor2 derived from Alpha5 injected into the nude mice. Our previous results have shown that Alpha5 and Tumor2 increased cell proliferation, anchorage independency, invasive capabilities and tumor formation in nude mice in comparison to control. Results indicated that curcumin decreased expression of EMT-related genes in Tumor 2 cell line when compared to its counterpart as E-cadherin, N-cadherin, ZEB2, Twist1, Slug, Axl, vimentin, STAT-3, fibronectin; and genes p53 and caveolin-1, as well as apoptotic genes caspase-3, caspase-8, and others such as cyclin $D 1$ and $N F \kappa B$. All these changes induced a decrease in migratory and invasive capabilities of such a cell line. Thus, it seems that curcumin may impinge upon apoptosis and metastatic properties of the malignant cells exerting antitumor activity in breast cancer cells transformed by low doses of $\alpha$-particles and estrogen in vitro.
\end{abstract}

\section{Introduction}

Breast cancer is the most frequent malignancy diagnosed in women in the western world. Oxidative stress is one of the important pathogenic factors of cancer development (1). Both in vitro and in vivo studies have shown that curcumin and its analogs target critical genes associated with angio-

Correspondence to: Dr Gloria M. Calaf, Instituto de Alta Investigación, Universidad de Tarapacá, Calle Antofagasta 1520, Arica 8097877, Chile

E-mail: gmc24@cumc.columbia.edu

Key words: curcumin, epithelial-mesenchymal transition, breast cancer cells, radiation genesis, apoptosis, cell cycle, and metastasis (1). Among the antioxidants, curcumin (1,7-bis(4-hydroxy-3-methoxyphenyl)1,6-heptadiene-3,5-dione; (diferuloylmethane) is a dietary natural yellow pigment derived from the rhizome of the turmeric herb known as Curcuma longa (Zingiberaceae) originating from India and South Asia. It is a polyphenol derived from several curcumin species, commonly known as turmeric which has been shown to inhibit carcinogen activation, modulate cell survival and apoptosis, with anti-invasive and anti-metastatic effects on breast, lung, colon and prostate cancer (1).

Epidemiological and experimental data demonstrated the efficacy of curcumin in chemoprevention and reversing chemoresistance of tumors of certain cancers. It possesses anti-proliferative and anti-carcinogenic potential $(2,3)$. Curcumin interferes with multiple genes that promote carcinogenesis. It is a pleiotropic molecule with anti-proliferative, antioxidant and chemopreventive properties. Alteration of gene expressions involved in key signaling pathways render this model an important tool for monitoring effects of natural dietary compounds in breast carcinogenesis (2).

One important concept of epithelial-mesenchymal transition (EMT), which has been recognized for several decades as a fundamental process of embryogenesis, is currently considered a pivotal event in the initial step of the metastatic cascade that allows cells to acquire migratory, invasive and stem-like properties (4).

During EMT of cancer cells in situ, epithelial cell layers lose polarity together with cell-to-cell contacts and then undergo a dramatic remodeling of the cytoskeleton. Changes in gene expression that promote cell-to-cell contact, such as E-cadherin and $\gamma$-catenin, may be lost and the cells may acquire mesenchymal characteristics such as changes at $N$-cadherin, vimentin, fibronectin levels resulting in an enhanced ability for cell migration and invasion (5). Cadherins are glycoproteins responsible for homotypic and calciumdependent cell-cell adhesion (6). E-cadherin is a membrane glycoprotein that plays an essential role in maintaining the integrity of cell-to-cell adhesion, which is significantly associated with tumor invasiveness and metastatic dissemination (7). Dysfunction or loss of E-cadherin is associated with an increased tendency for tumor metastasis (8). In addition, degradation of extracellular matrix and basement membranes by the tumor cells is a critical step and occurs at several stages 
of the metastatic cascade $(9,10)$. $N$-cadherin (cadherin-2 or $\mathrm{CDH}-2$ ) is a mesenchymal cadherin overexpressed in many cancers and associated with cancer cell migration and FGF receptor signaling in breast cancer metastasis (11). $\beta$-catenin is a $92 \mathrm{kDa}$ protein that plays a role in both cell adhesion and intracellular signaling (12) as the classical cadherins which play fundamental roles in the development of multicellular organisms (13).

Smad interacting protein 1 (SIP1; also known as ZEB2, for zinc finger E-box-binding protein 2 and $Z F H X 1 B$ ) belongs to the $\delta E F-1$ or ZEB protein family (14) and are transcriptional factors characterized by containing a homeo domain flanked by two separated zinc finger clusters (15). It is expressed in various types of human tumors, such as breast cancer, gastric cancer and ovarian cancer (15). ZEB2 is a potent repressor of E-cadherin through its direct binding to the E-cadherin promoter and a key player in tumor cell invasion and metastasis $(16,17)$.

Twist1 induces EMT and extracellular matrix degradation in tumor progression (18-20). Slug is a member of the SNAI family of $\mathrm{C} 2 \mathrm{H} 2$-zinc finger family of transcriptional repressors (21-23). It is involved in the EMT during development (22), acts as an inhibitor of apoptosis (24), and causes tubulogenesis during breast and kidney developments $(21,22)$. AXL is a member of the TAM (Tyro3, Axl, Mer) family of receptor tyrosine kinases (RTK), originally identified as a transforming gene in cells of chronic myelogenous leukemia patients. It is activated through several mechanisms, including binding of its ligand, growth arrest specific 6 (Gas6), and extracellular domain-mediated dimerization or crosstalk with HER2/neu (25-27). Vimentin belongs to intermediate filaments that with microfilaments and microtubules are the major cytoskeletal elements of the cell $(28,29)$.

STAT-3, a versatile member of the family known as signal transducers and activators of transcription (STAT) mediates the axial responses of cytokines. STAT-3 is involved in normal cellular responses, as well as oncogenesis (30). Fibronectin is a component of the extracellular matrix and exerts multiple effects in vitro and in vivo including stimulation of cell proliferation, migration, differentiation and survival (31-34). It affects cell behavior through activation of various cell surface receptors most notably integrins (35). Fibronectin is required for the development of fibrillar structures (36) and for the storage and activation of various growth factors (37).

The $p 53$ gene is known as the guardian of the genome (38). A major biological function of p53 is to respond to stress signals and activate the transcription of downstream target genes involved in important cellular mechanisms like cell cycle control, DNA repair and apoptosis. Caveolin is a specialized lipid raft on the plasma membrane found in mesenchymal cells. The caveolin family consists of three members, caveolin-1 (Cav-1), caveolin-2 and caveolin-3. Cav-1 is widely expressed in various tissues and plays an essential role in a number of human diseases including cancer (39).

Apoptosis is genetic death program (40). The balance between pro- and anti-apoptotic signals maintain biological homeostasis and its imbalance is related to malignant transformation (40). The central component of the apoptotic machinery is the family of caspases $(41,42)$. The members of the caspase family can be divided into two groups: i) upstream initiator caspases, such as caspase- 8 and ii) downstream effector caspases, such as caspase-3 $(43,44)$.

Cyclins, cyclin-dependent kinases (cdks) have been identified as regulatory subunits (cyclins) and catalytic subunits (cdks) of cell cycle-regulated kinases involved in the control of mitosis. It is involved in regulating the $\mathrm{G} 1$ to $\mathrm{S}$ transition $(45,46)$. Abnormalities involving cyclin D1 may deregulate control of the G1-S transition and, therefore, contribute to genomic instability and tumor development $(45,46)$. Cyclin D1 along with its binding partners CDK 4/6 partially mediate G1 to S-phase transition of the cell cycle through phosphorylation and inactivation of retinoblastoma $(\mathrm{Rb})$ protein with subsequent release of E2F transcription factors (47-49). It is believed that the oncogenic properties of cyclin D1 depend to a large extent on its ability to activate cyclin-dependent kinases 4 or $6(\mathrm{Cdk} 4 / 6)(50,51)$.

Nuclear Factor $\kappa \mathrm{B}(\mathrm{NF} \kappa \mathrm{B})$ is a complex of transcription factors that function in the development of acquired resistance to several other targeted agents (52). NFkB signaling has two major pathways, one is the canonical pathway that mainly modulates cell proliferation, inflammation or anti-apoptosis, and the other one is the non-canonical pathway that mainly controls lymphogenesis (53).

To gain insights into the effects of curcumin on breast carcinogenesis an established in vitro experimental breast cancer model (Alpha model) (54) was used. It was developed with the immortalized human breast epithelial cell line, MCF-10F (55) that was exposed to low doses of high LET (linear energy transfer) $\alpha$-particles $(150 \mathrm{keV} / \mu \mathrm{m})$ of radiation, values comparable to $\alpha$-particles emitted by radon progeny, and subsequently cultured in presence or absence of $17 \beta$-estradiol (estrogen). MCF-10F was exposed to low doses of high LET $\alpha$-particles (150 keV/microm) and subsequently cultured in the presence or absence of 17beta-estradiol (E) for periods of up to 10 months post-irradiation. MCF-10F cells irradiated with either a single 60 cGy dose or 60/60 cGy doses of $\alpha$-particles showed gradual phenotypic changes including altered morphology, increase in cell proliferation relative to the control, anchorageindependent growth and invasive capability before becoming tumorigenic in nude mice. In addition, these cells present all the characteristics of breast epithelium in their ultra structural features (56-58). However, only those MCF-10F cells treated with a 60 cGy dose of $\alpha$-particles followed by estrogen treatment and exposed to a second dose of $60 \mathrm{cGy}$ dose of $\alpha$-particles followed by estrogen $(60 \mathrm{cGy}+\mathrm{E} / 60 \mathrm{cGy}+\mathrm{E})$, named Alpha5 became tumorigenic in both SCID and nude mice (54). Tumor2 developed from Alpha5 injected in the athymic mice. The aim of this work was to evaluate the effect of curcumin on epithelial mesenchymal transition and other related genes in breast cancer cells transformed by low doses of $\alpha$-particles and estrogen.

\section{Materials and methods}

Breast cancer cell lines. The spontaneously immortalized breast epithelial cell line, MCF-10F cells was grown in DMEM/F-12 (1:1) medium supplemented with antibiotics $100 \mathrm{U} / \mathrm{ml}$ penicillin, $100 \mu \mathrm{g} / \mathrm{ml}$ streptomycin, $2.5 \mu \mathrm{g} / \mathrm{ml}$ amphotericin B (all from Life Technologies, Grand Island, NY, USA) and $10 \mu \mathrm{g} / \mathrm{ml}$ and 5\% equine serum (Biofluids, Rockville, 
Table I. Primers for genes selected to develop cDNA probes.

\begin{tabular}{|c|c|c|}
\hline Gene name & $\begin{array}{l}\text { Product } \\
\text { length } \\
(\mathrm{bp})^{\mathrm{a}}\end{array}$ & Primer sequence $^{b}$ \\
\hline E-cadherin & 93 & $\begin{array}{l}\text { F: AGTGGGCACAGATGGTGTGA } \\
\text { R: TAGGTGGAGTCCCAGGCGTA }\end{array}$ \\
\hline$N$-cadherin & 67 & $\begin{array}{l}\text { F: TCG ATT GGT TTG ACC ACG G } \\
\text { R: GAC GGT TCG CCA TCC AGA C }\end{array}$ \\
\hline$\beta$-catenin & 94 & $\begin{array}{l}\text { F: GCAGAGTGCTGAAGGTGCTA } \\
\text { R: TCTGTCAGGTGAAGTCCTAAAGC }\end{array}$ \\
\hline$Z E B 2$ & 128 & $\begin{array}{l}\text { F: CAAGAGGCGCAAACAAGC } \\
\text { R: GGTTGGCAATACCGTCATCC }\end{array}$ \\
\hline Twist 1 & 118 & $\begin{array}{l}\text { F: TCCGCGTCCCACTAGCA } \\
\text { R:AGTTATCCAGCTCCAGAGTCTCTAGAC }\end{array}$ \\
\hline Slug & 72 & $\begin{array}{l}\text { F: GACCCTGGTTGCTTCAAGGA } \\
\text { R: TGTTGCAGTGAGGGCAAGAA }\end{array}$ \\
\hline$A X L$ & 121 & $\begin{array}{l}\text { F: GTTTGGAGCTGTGATGGAAGGC } \\
\text { R: CGCTTCACTCAGGAAATCCTCC }\end{array}$ \\
\hline Vimentin & 117 & $\begin{array}{l}\text { F: TGTCCAAATCGATGTGGATGTTTC } \\
\text { R: TTGTACCATTCTTCTGCCTCCTG }\end{array}$ \\
\hline STAT-3 & 163 & $\begin{array}{l}\text { F: GGTTGGACATGATGCACACTAT } \\
\text { R: AGGGCAGACTCAAGTTTATCAG }\end{array}$ \\
\hline Fibronectin & 105 & $\begin{array}{l}\text { F: GGAGGAAGCCGAGGTTTTAAC } \\
\text { R: ACGCTCATAAGTGTCACCCA }\end{array}$ \\
\hline mp53 & 128 & $\begin{array}{l}\text { F: CCTCAGCATCTTATCCGAGTGG } \\
\text { R: TGGATGGTGGTACAGTCAGAGC }\end{array}$ \\
\hline Caveolin-1 & 79 & $\begin{array}{l}\text { F: AACGATGACGTGGTCAAGATTG } \\
\text { R: TCCAAATGCCGTCAAAACTGT }\end{array}$ \\
\hline Caspase-3 & 192 & $\begin{array}{l}\text { F: CAGAACTGGACTGTGGCATTG } \\
\text { R: GCTTGTCGGCATACTGTTTCA }\end{array}$ \\
\hline Caspase- 8 & 128 & $\begin{array}{l}\text { F: CATCCAGTCACTTTGCCAGA } \\
\text { R: GCATCTGTTTCCCCATGTTT }\end{array}$ \\
\hline Cyclin D1 & 60 & $\begin{array}{l}\text { F: GTGGCCTCTAAGATGAAGGA } \\
\text { R: GGTGTAGATGCACAGCTTCT }\end{array}$ \\
\hline$N F \kappa B$ & 114 & $\begin{array}{l}\text { F: ATCTGCCGAGTGAACCGAAACT } \\
\text { R: CCAGCCTGGTCCCGTGAAA }\end{array}$ \\
\hline
\end{tabular}

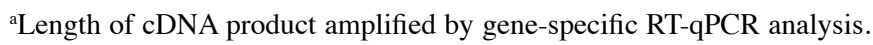
${ }^{b} \mathrm{PCR}$ primer sequences used to generate a product of the indicated size, listed in $5^{\prime}$ to $3^{\prime}$ orientation; $\mathrm{F}$, forward; $\mathrm{R}$, reverse.

MD, USA), $0.5 \mu \mathrm{g} / \mathrm{ml}$ hydrocortisone (Sigma, St. Louis, MO, USA) and $0.02 \mu \mathrm{g} / \mathrm{ml}$ epidermal growth factor (Collaborative Research, Bedford, MA, USA). An in vitro experimental breast cancer model developed by exposure of the immortalized human breast epithelial cell line was used. MCF-10F was exposed to low doses of high LET (linear energy transfer) $\alpha$-particles radiation $(150 \mathrm{keV} / \mu \mathrm{m})$ and subsequent growth in the presence or absence of $17 \beta$-estradiol at $10^{-8} \mathrm{M}(\mathrm{E}$ or Estrogen) (Sigma-Aldrich, St. Louis, MO, USA). The following cell line consisted of human breast epithelial cells in different stages of transformation: i) a control cell line, MCF-10F; ii) Alpha5 and iii) Tumor2 (54).

RNA extraction and cDNA synthesis. RNA from cells were obtained using TRIzol reagent (Invitrogen Corp., Carlsbad, CA, USA) following to the manufacturer's protocol. RNA $(2 \mu \mathrm{g})$ were reverse-transcribed to cDNA with kit High capacity cDNA Reverse Transcription (Applied Biosystems, Carlsbad, CA, USA).

$R T$ - $q P C R$. Synthesized cDNA $(2 \mu \mathrm{l})$ was mixed in $20 \mu \mathrm{l} \mathrm{qPCR}$ reaction containing SYBR Green PCR Master Mix (Agilent, La Jolla, CA, USA) and $5 \mu \mathrm{M}$ of primers for the target genes such as E-cadherin, $N$-cadherin, $\beta$-catenin, ZEB2, Twist, Slug, Axl, vimentin, STAT-3, fibronectin, p53, caveolin-1, caspase-3, caspase-8, cyclin DI and $N F \kappa B$. Table I shows the primers to develop cDNA probes. CFX 96 Touch Real-time PCR Detection Systems (Bio-Rad Laboratories, Hercules, CA, USA) was used to perform the reaction with the following conditions: $95^{\circ} \mathrm{C}$ for $10 \mathrm{~min}$ and 40 cycles of a 2-step program of $95^{\circ} \mathrm{C}$ for $10 \mathrm{sec}$ and $61^{\circ} \mathrm{C}$ for $45 \mathrm{sec}$. Reactions were performed in triplicate. Threshold cycle $(\mathrm{Ct})$ was obtained using Bio-Rad CFX Manager 2.1 software. Gene expression was normalized using $\beta$-actin. Relative expression was always normalized to the average breast cells and its counterparts.

Cell migration and invasion assays. Migration and invasiveness were performed using modified Boyden's chambers (Corning, Inc., Corning, NY, USA) constructed with multiwell cell culture plates and cell culture inserts. The upper chambers of Transwells with $8-\mu \mathrm{m}$ membrane pores were pre-coated with $60 \mu 1$ Matrigel matrix gel (BD Biosciences) at least $1 \mathrm{~h}$ before seeding of the tested cells (54). A total of $3 \times 10^{5}$ in $100 \mu \mathrm{l}$ of medium without fetal bovine serum was added into the upper chambers and $600 \mu \mathrm{l}$ of medium with $10 \%$ FBS was placed to lower chambers as chemoattractant. Cells were cultured for $48 \mathrm{~h}$ following treatment. Curcumin $(30 \mu \mathrm{M})$ was added to the cell culture. Normal culture medium was added at the bottom chamber to induce the cancer cell lines. Cells which were pretreated were seeded in the top chamber. The matrigel invasion chamber was incubated for $16 \mathrm{~h}$ in a humidified tissue culture incubator. Then, the upper chambers were removed from lower chambers and then wiped using cotton swabs. The invaded and migrated cells were fixed using $100 \%$ methanol at room temperature for $15 \mathrm{~min}$, visualized and quantified using DAPI. Three fields of each chamber were photographed (x40 magnification). This experiment was independently repeated at least twice.

Statistical analysis. Numerical data were expressed as the average \pm standard error of the mean (SEM). Comparison between treated groups and controls was carried out by ANOVA and Dunnet's test. A P $<0.05$ was considered to be significant.

\section{Results}

Curcumin inhibited the expression of markers of EMT such as E-cadherin, $\mathrm{N}$-cadherin, $\beta$-catenin and ZEB2 in breast cancer cells (Fig. 1A-D). Results in Fig. 1A-D show a decrease in 
A

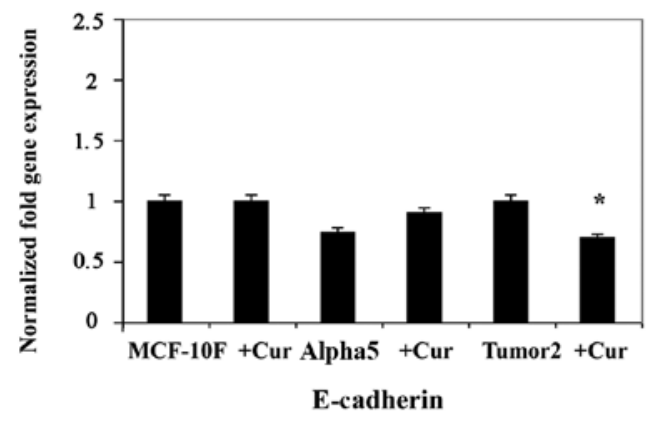

C

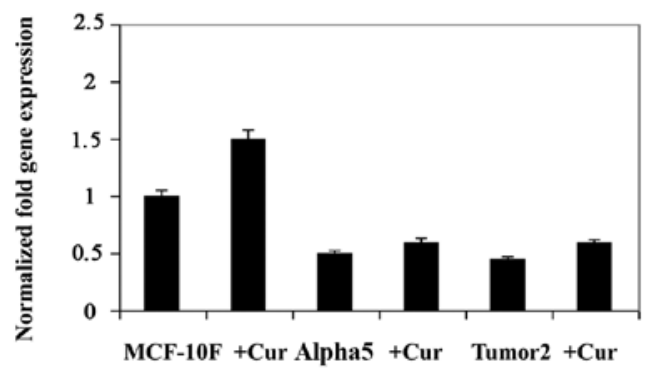

$\beta$-catenin
B

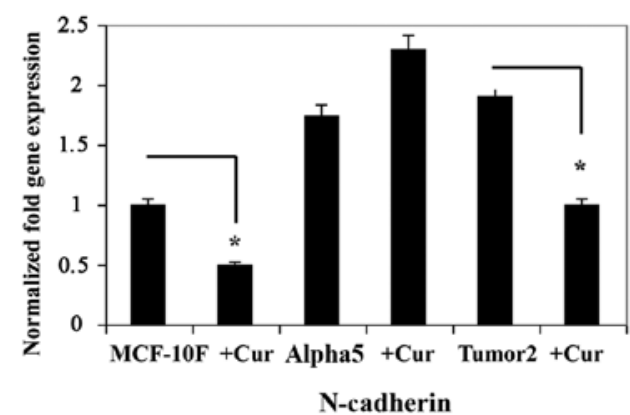

D

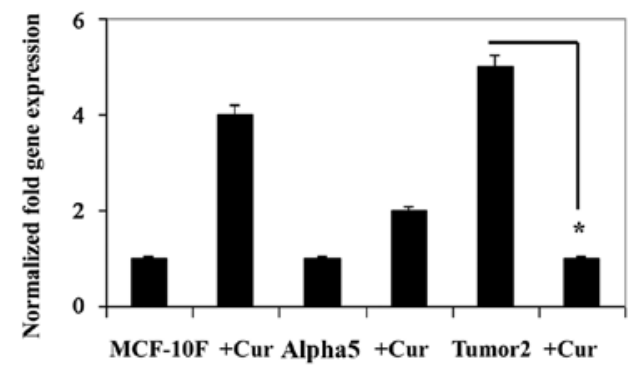

ZEB2

Figure 1. Effect of curcumin on (A) E-cadherin, (B) N-cadherin, (C) $\beta$-catenin and (D) ZEB2 gene expression in MCF-10F, Alpha5 and Tumor2 cell lines analyzed by RT-qPCR. Graphs represent the relative grade of luminescence to assess the gene level of the cell lines. Bars represent the mean \pm SEM of three independent experiments. ${ }^{*} \mathrm{P}<0.05$ versus counterpart.

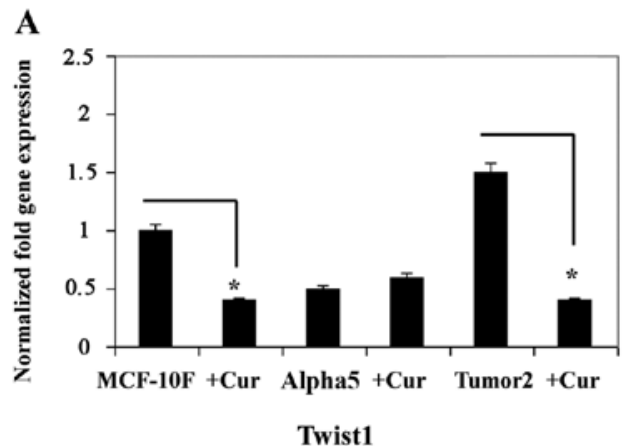

C

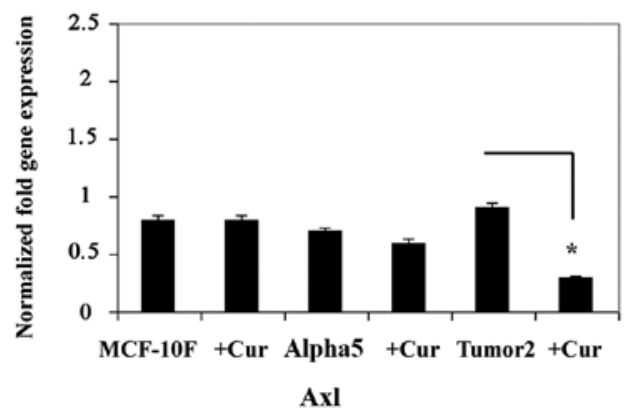

B

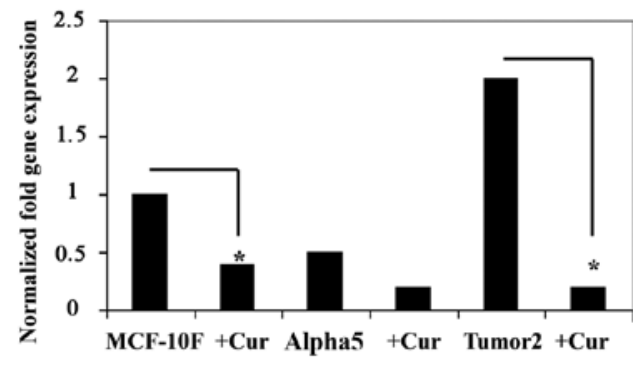

Slug

D

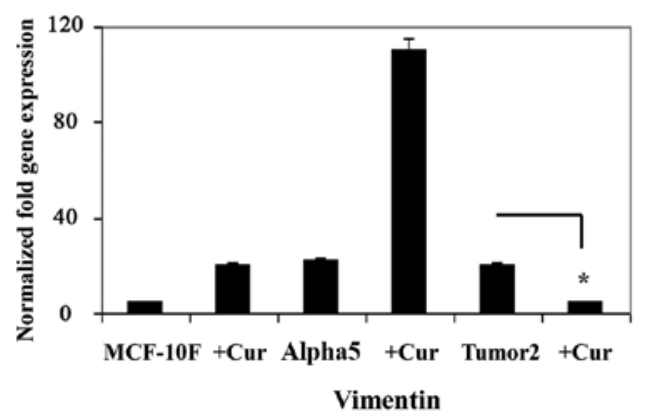

Figure 2. Effect of curcumin on (A) Twist1, (B) Slug, (C) Axl and (D) Vimentin gene expression in MCF-10F, Alpha5 and Tumor2 cell lines studied by RT-qPCR. Graphs represent the relative grade of luminescence to assess the gene level of the cell lines. Bars represent the mean \pm SEM of three independent experiments. ${ }^{*} \mathrm{P}<0.05$ versus counterpart.

E-cadherin (Fig. 1A), N-caherin (Fig. 1B), $\beta$-catenin (Fig. 1C), and ZEB2 (Fig. 1D) gene expression in MCF-10F and Tumor2 $(\mathrm{P}<0.01)$ in comparison with its counterparts. However, there was no difference in Alpha5 cell line. Results in Fig. 2A-D show a decrease in other EMT-related genes Twist (Fig. 2A), Slug (Fig. 2B), Axl (Fig. 2C), and vimentin (Fig. 2D) gene expression in MCF-10F and Tumor2. However, there was no difference in Alpha5 cell line. 
A

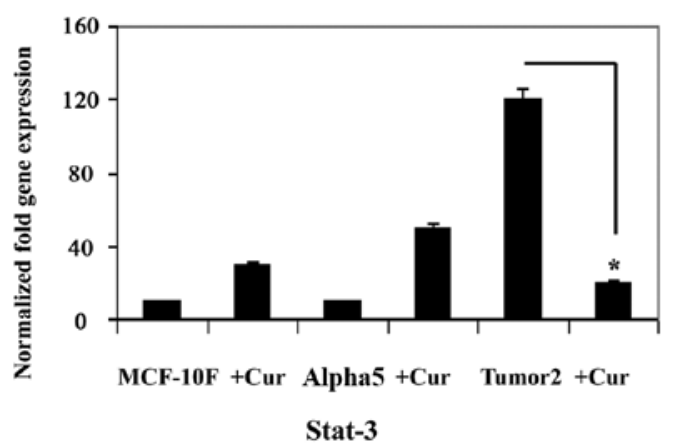

C

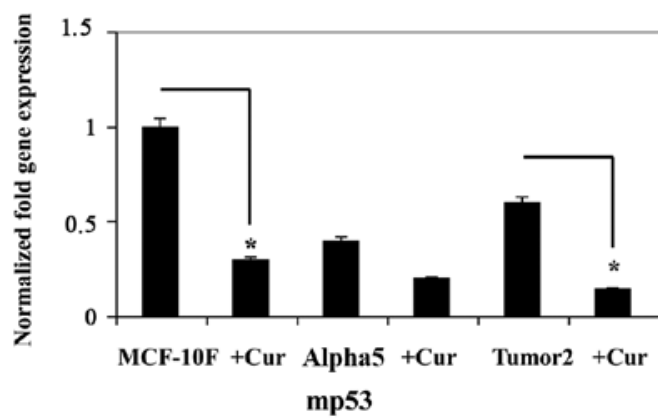

B

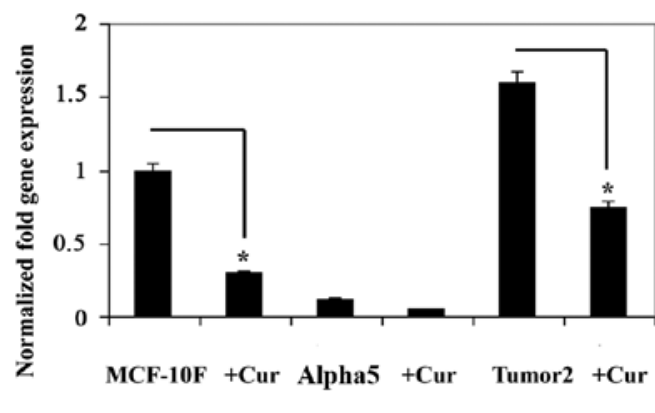

Fibronectin

D

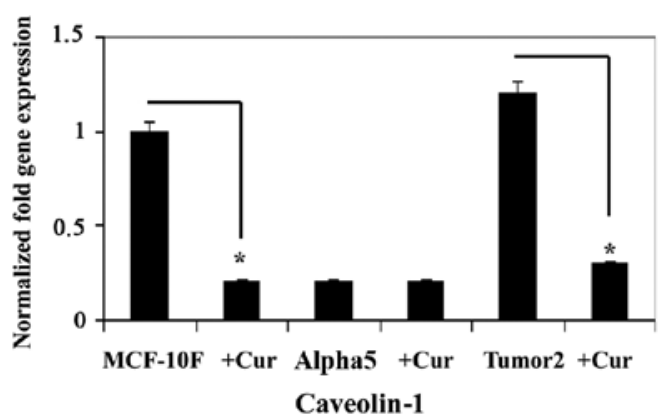

Figure 3. Effect of curcumin on (A) Stat3, (B) Fibronectin, (C) $m p 53$, (D) Caveolin-1 gene expression in MCF-10F, Alpha5 and Tumor2 cell lines analyzed by RT-qPCR. Graphs represent the relative grade of luminescence to assess the gene level of the cell lines. Bars represent the mean \pm SEM of three independent experiments. ${ }^{*} \mathrm{P}<0.05$ versus counterpart.

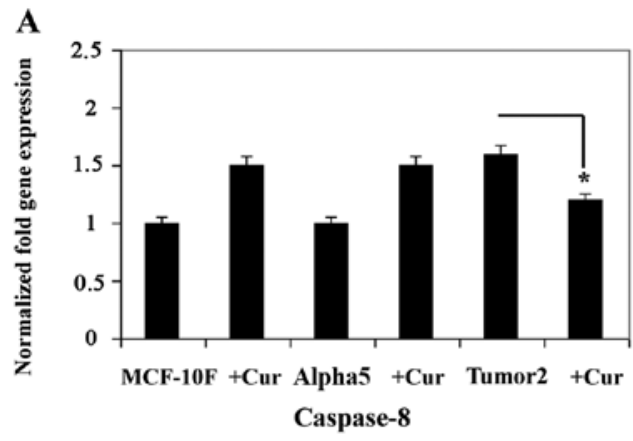

C

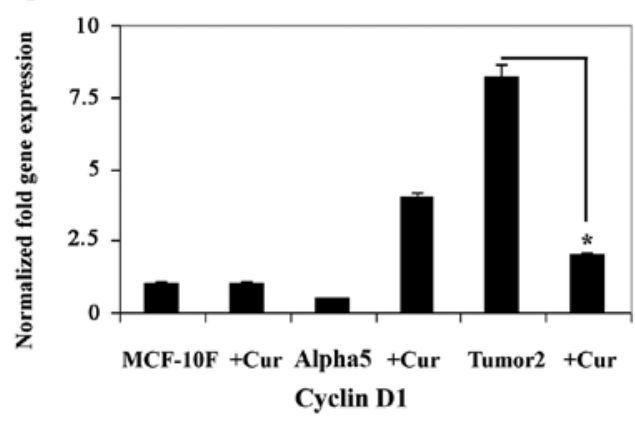

B

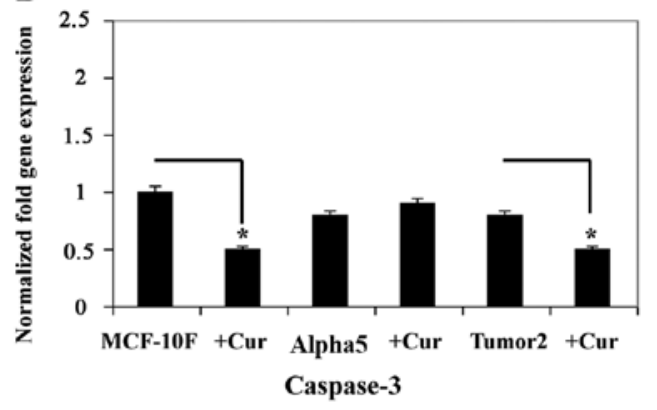

D

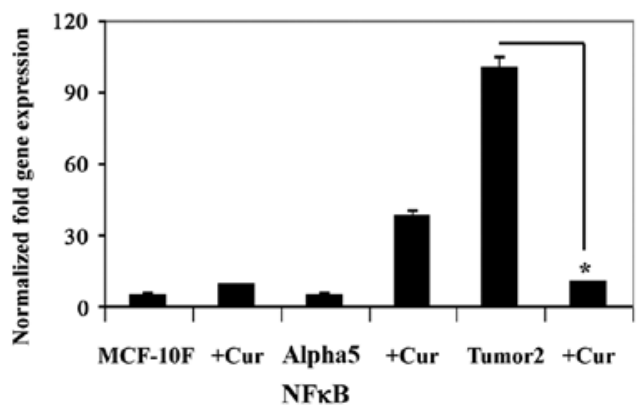

Figure 4. Effect of curcumin on (A) caspase-8, (B) caspase-3, (C) cyclin D1 and (D) $N F \kappa B$ gene expression in MCF-10F, Alpha5 and Tumor2 cell lines analyzed by RT-qPCR. Graphs represent the relative grade of luminescence to assess the gene level of the cell lines. Bars represent the mean \pm SEM of three independent experiments. ${ }^{*} \mathrm{P}<0.05$ versus counterpart.

Curcumin induced a decrease in gene expression as shown in Figs. 3 and 4A-D for STAT-3 (Fig. 3A), fibronectin (Fig. 3B), mp53 (Fig. 3C), and Cavl (Fig. 3D), caspase-8 (Fig. 4A), caspase-3 (Fig. 4B), cyclin Dl (Fig. 4C) and $N F \kappa B$ (Fig. 4D) in the malignant and tumorigenic cell line Tumor2 $(\mathrm{P}<0.01)$ in comparison with its counterpart. However, there was no difference in Alpha5 cell line in comparison with its counterpart. Since EMT is associated with cellular progression we studied 
A

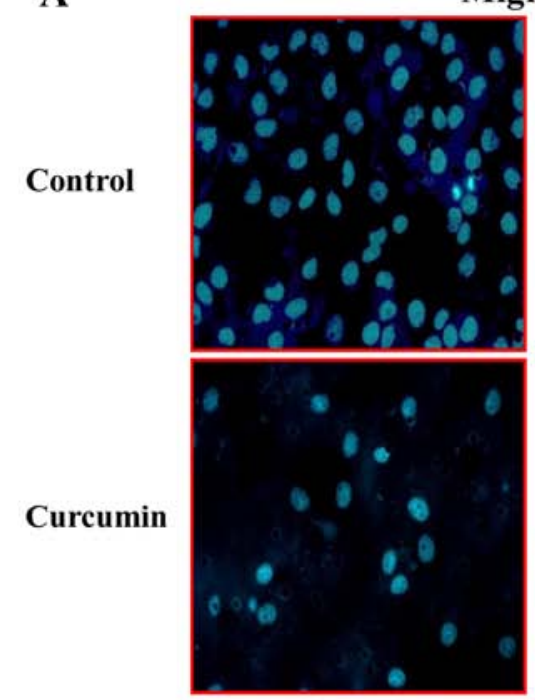

MCF-10F
Migration
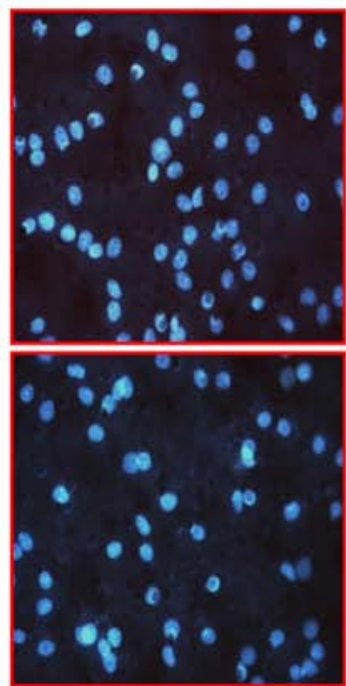

Tumor2
B
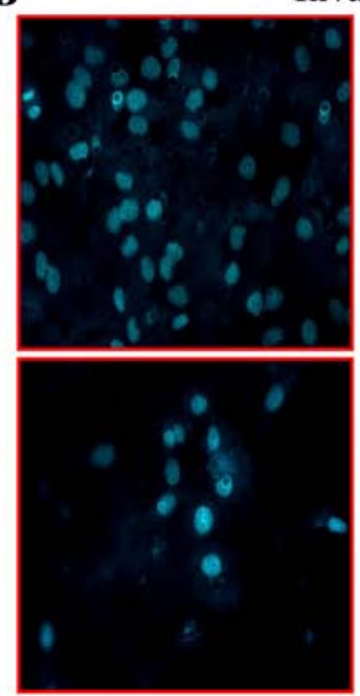

MCF-10F
Invasion

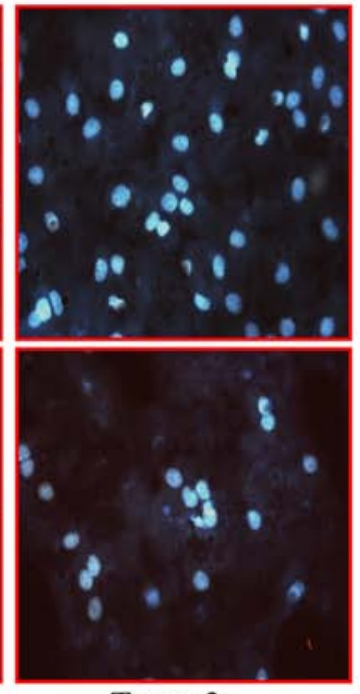

Tumor2

C

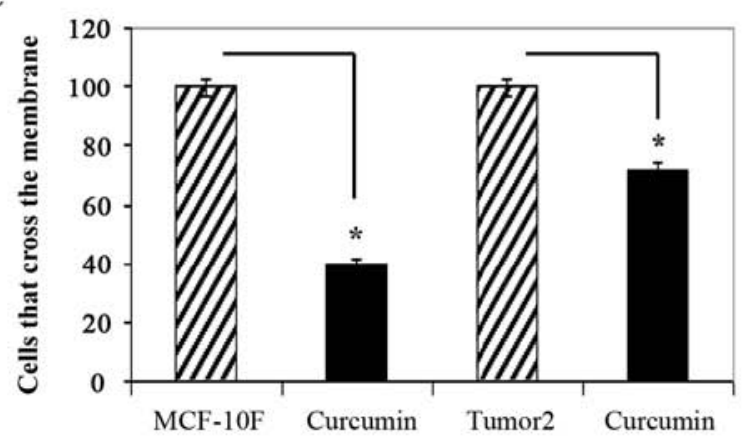

D

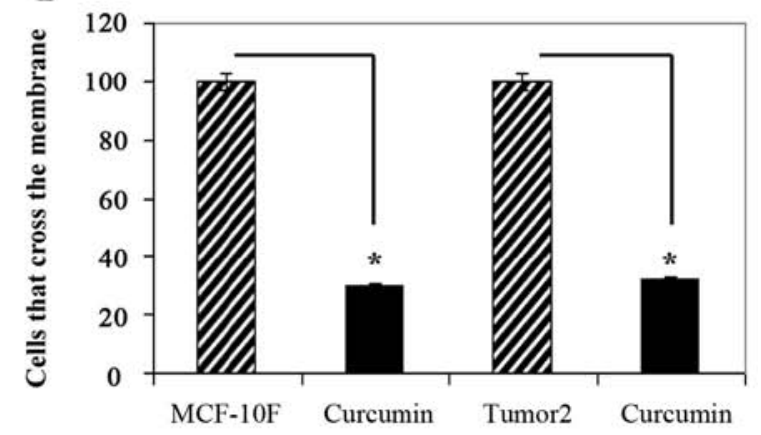

Figure 5. Effect of curcumin on (A) migration and (B) invasion in MCF-10F and Tumor2 cell lines analyzed by modified Boyden's chambers (Corning Inc., Corning, NY, USA) constructed with multiwell cell culture plates and cell culture inserts. The upper chambers of Transwells with 8 - $\mu \mathrm{m}$ membrane pores were pre-coated with $60 \mu \mathrm{l}$ Matrigel matrix gel at least $1 \mathrm{~h}$ before seeding of the tested cells. A total of $3 \times 10^{5}$ in $100 \mu 1$ of medium without fetal bovine serum was added into the upper chambers and $600 \mu \mathrm{l}$ of medium with $10 \%$. (C and D) Graphs that represent the relative grade of luminescence in relation to migration and invasion from $100 \%$ of the counterpart, respectively. Bars represent the mean \pm SEM of three independent experiments. ${ }^{*} \mathrm{P}<0.05$ versus counterpart.

the effect on migration and invasion of breast cancer cells. Curcumin decreased the number of migratory and invasive cells significantly $(\mathrm{P}<00.5)$ compared to the untreated cells as can be observed in Fig. 5.

\section{Discussion}

Accumulating evidences suggest that curcumin has a diverse range of molecular targets, supporting the concept that it acts upon numerous biochemical and molecular cascades. Despite our increasing knowledge on this interesting substance there still remain many unknown effects that deserve intense investigation. The multi-targeting of curcumin comes from its structure, chemistry and influence on multiple signaling molecules as well as its ability to bind directly to carrier proteins that improves its solubility and bioavailability. It binds to DNA and RNA. Both in vitro and in vivo studies have shown that curcumin and its analogs target critical genes associated with angiogenesis, apoptosis, cell cycle, and metastasis.

The MCF-10F is unique in the sense that it retains all the characteristics of normal breast epithelium in vitro including dome formation in confluent cultures, three-dimensional growth in collagen gel (55), dependence upon hormones and growth factors for growth in vitro, lack of anchorageindependence or invasive capabilities and non-tumorigenic in the nude or SCID mice (54). It was previously shown $(59,60)$ that among all the various transformed human breast cell lines only Alpha5 cell line and Tumor 2 increased cell proliferation, adhesion, presented anchorage-independency, invasive capabilities and tumor formation in nude mice. These cell lines were also positive for estrogen receptor, progesterone receptor and HER, c-Ha-ras and Rho-A gene and protein expression.

EMT is associated with enhanced cellular progression. Curcumin inhibited EMT gene expression in breast cancer cells as E-cadherin, $N$-cadherin, $\beta$-catenin and ZEB2 in Tumor 2 in comparison with its counterparts. Curcumin also inhibited Twistl, Slug, Axl and vimentin gene expression in the same cell line. It is known that Twistl promotes stationary epithelial cells to lose cell-cell junctions and gain migratory and invasive capacities (61); Slug acts as an inhibitor of apoptosis (24) and Axl is overexpressed in a wide variety of human cancers with significant correlation with tumor stage in breast cancer patients playing an important role in cancer progression and metastases (62-64). Curcumin decreased STAT-3 
and fibronectin gene expression in Tumor 2 in comparison to its counterpart. It is known that STAT-3 mediates the axial responses of cytokines involved in normal cellular responses and oncogenesis (30).

The antioxidant inhibited $\mathrm{Cav}-1$ gene expression of malignant and tumorigenic cell line Tumor2. It has been reported that inhibition of the tumor promoter Cav-1 expression in Hca-F cells prevents EMT formation by increasing stabilization of Cav-1 with $\beta$-catenin $(65,66)$. Curcumin induced tumor cell apoptosis since it decreased caspase-3, caspase- 8 and cyclin $\mathrm{Dl}$ expression in Tumor2 in comparison to its control. Abnormalities involving cyclin D1 may alter G1-S transition and contribute to genomic instability and tumor development $(45,46)$. The ability of curcumin to induce apoptosis in tumor cells and/or potentiate apoptosis induction by classical chemotherapeutic drugs, support its potential in anticancer therapies $(67,68)$. This substance also inhibited the $m p 53$ gene expression of malignant and tumorigenic cell line Tumor 2 in comparison to its control. Of note, curcumin has been found to inhibit proliferation of normal, non-selectively, as well as malignant cells, although its apoptogenic effect is more profound in malignant cells since it selectively induced apoptosis in deregulated cyclin D1-expressed cells at G2 phase of cell cycle in a p53-dependent manner $(69,70)$. The possibility that $\mathrm{p} 53$-mediated apoptosis may be associated with the activation of caspase- 3 and caspase- 8 is suggested by the ability of p53 to activate both the extrinsic and intrinsic apoptotic pathways (71). It has been reported that $\mathrm{p} 53$ activates effector caspases by possibly inducing the release of mitochondrial cytochrome-c, including caspase-3, and caspase-8 and through the apoptotic effector machinery engaged by $p 53$ (72,73). It has been reported that p53 enhances cancer cell apoptosis and prevents cell replication by stopping the cell cycle at G1 or interphase (74).

Curcumin induced a reduction of tumor cell invasion and metastasis along with apoptosis. The motile phenotypes of cells treated with curcumin were evaluated by migration and invasion assay. After treatment with curcumin the number of migratory and invasive cells decreased significantly compared to the untreated cells. Curcumin has been reported to inhibit cell proliferation and promote accumulation of cells in the G2/M phase of the cell cycle (75).

Thus, the mechanism of apoptosis induced by curcumin seems to be through reduction of tumor cell invasion and metastasis by $\mathrm{NF \kappa B}$. The authors (76) showed that $\mathrm{NF \kappa B}$, a transcription factor in the cell was altered by curcumin. Curcumin plays an important role in the inhibition of EMT in breast cancer cells through the downregulation of NFKB-Snail activity (77). These data provide a new perspective of the antiinvasive mechanism of curcumin, indicating that the effect is partly due to its ability to intervene in the EMT process (77). The inhibition of human breast cancer cell growth by curcumin is mediated via certain signaling cascades including the modulation of the $\mathrm{NFKB}$ signaling pathway.

Several studies in vitro and first clinical investigations confirm the antitumor effects of curcumin, either as an isolated chemoprevention substance or in combination with chemotherapeutic agents as supportive measure reducing pharmaceutical resistance of tumor cells to certain chemotherapeutics. The ability of curcumin to induce apoptosis in tumor cells by a classical chemotherapeutic drug, or an antioxidant such as curcumin supports its potential in anticancer therapies. Despite our increasing knowledge on this interesting substance there still remain many unknown effects that deserve intense investigation. These studies reveal the inhibitory effect of curcumin with emphasis on multi-targeted biological and molecular effects in a breast cancer model. Thus, it seems that curcumin may impinge upon several processes including apoptosis and metastatic properties of the malignant cells exerting antitumor activity in breast cancer cells transformed by low doses of $\alpha$-particles and estrogen in vitro.

\section{Acknowledgements}

The technical support of Guiliana Rojas, Georgina Vargas Marchant and Leodán A. Crispin and helpful suggestions given by Richard Ponce-Cusi are greatly appreciated. This study was supported by Grant support FONDECYT \#1120006 (G.M.C.) and MINEDUC-UTA (G.M.C.).

\section{References}

1. Kelloff GJ, Crowell JA, Steele VE, Lubet RA, Malone WA, Boone CW, Kopelovich L, Hawk ET, Lieberman R, Lawrence JA, et al: Progress in cancer chemoprevention: Development of dietderived chemopreventive agents. J Nutr 130 (Suppl): 467S-471S, 2000.

2. Khar A, Ali AM, Pardhasaradhi BV, Varalakshmi CH, Anjum R and Kumari AL: Induction of stress response renders human tumor cell lines resistant to curcumin-mediated apoptosis: Role of reactive oxygen intermediates. Cell Stress Chaperones 6: 368-376, 2001.

3. Ramachandran C, Rodriguez S, Ramachandran $\mathrm{R}$, Raveendran Nair PK, Fonseca H, Khatib Z, Escalon E and Melnick SJ: Expression profiles of apoptotic genes induced by curcumin in human breast cancer and mammary epithelial cell lines. Anticancer Res 25: 3293-3302, 2005.

4. Cowin P and Welch DR: Breast cancer progression: Controversies and consensus in the molecular mechanisms of metastasis and EMT. J Mammary Gland Biol Neoplasia 12: 99-102, 2007.

5. Moreno-Bueno G, Portillo F and Cano A: Transcriptional regulation of cell polarity in EMT and cancer. Oncogene 27: 6958-6969, 2008.

6. Yap AS, Brieher WM, Pruschy M and Gumbiner BM: Lateral clustering of the adhesive ectodomain: A fundamental determinant of cadherin function. Curr Biol 7: 308-315, 1997.

7. Carneiro P, Figueiredo J, Bordeira-Carriço R, Fernandes MS, Carvalho J, Oliveira $\mathrm{C}$ and Seruca R: Therapeutic targets associated to E-cadherin dysfunction in gastric cancer. Expert Opin Ther Targets 17: 1187-1201, 2013.

8. Onder TT, Gupta PB, Mani SA, Yang J, Lander ES and Weinberg RA: Loss of E-cadherin promotes metastasis via multiple downstream transcriptional pathways. Cancer Res 68: 3645-3654, 2008.

9. Pal S, Ganguly KK and Chatterjee A: Extracellular matrix protein fibronectin induces matrix metalloproteinases in human prostate adenocarcinoma cells PC-3. Cell Commun Adhes 20: 105-114, 2013.

10. Wang H, Zhu Y, Zhao M, Wu C, Zhang P, Tang L, Zhang H, Chen X, Yang Y and Liu G: miRNA-29c suppresses lung cancer cell adhesion to extracellular matrix and metastasis by targeting integrin $\beta 1$ and matrix metalloproteinase2 (MMP2). PLoS One 8: e70192, 2013.

11. Hulit J, Suyama K, Chung S, Keren R, Agiostratidou G, Shan W, Dong X, Williams TM, Lisanti MP, Knudsen K, et al: N-cadherin signaling potentiates mammary tumor metastasis via enhanced extracellular signal-regulated kinase activation. Cancer Res 67: 3106-3116, 2007.

12. Mandal A, Bhatia D and Bishayee A: Simultaneous disruption of estrogen receptor and Wnt $/ \beta$-catenin signaling is involved in methyl amooranin-mediated chemoprevention of mammary gland carcinogenesis in rats. Mol Cell Biochem 384: 239-250, 2013. 
13. Nichols SA, Roberts BW, Richter DJ, Fairclough SR and King N: Origin of metazoan cadherin diversity and the antiquity of the classical cadherin/ $\beta$-catenin complex. Proc Natl Acad Sci USA 109: 13046-13051, 2012.

14. Verschueren K, Remacle JE, Collart C, Kraft H, Baker BS Tylzanowski P, Nelles L, Wuytens G, Su MT, Bodmer R, et al: SIP1, a novel zinc finger/homeodomain repressor, interacts with Smad proteins and binds to 5'-CACCT sequences in candidate target genes. J Biol Chem 274: 20489-20498, 1999.

15. Katoh $M$ and Katoh M: Integrative genomic analyses of ZEB2: Transcriptional regulation of ZEB2 based on SMADs, ETS1, HIF1 $\alpha$, POU/OCT, and NF- $\kappa$ B. Int J Oncol 34: 1737-1742, 2009.

16. Nam EH, Lee Y, Park YK, Lee JW and Kim S: ZEB2 upregulates integrin $\alpha 5$ expression through cooperation with $\mathrm{Spl}$ to induce invasion during epithelial-mesenchymal transition of human cancer cells. Carcinogenesis 33: 563-571, 2012.

17. Zhao C, Qiao Y, Jonsson P, Wang J, Xu L, Rouhi P, Sinha I, Cao Y, Williams C and Dahlman-Wright K: Genome-wide profiling of AP-1-regulated transcription provides insights into the invasiveness of triple-negative breast cancer. Cancer Res 74 3983-3994, 2014

18. Yang J, Mani SA, Donaher JL, Ramaswamy S, Itzykson RA, Come C, Savagner P, Gitelman I, Richardson A and Weinberg RA: Twist, a master regulator of morphogenesis, plays an essential role in tumor metastasis. Cell 117: 927-939, 2004.

19. Casas E, Kim J, Bendesky A, Ohno-Machado L, Wolfe CJ and Yang J: Snail2 is an essential mediator of Twist1-induced epithelial mesenchymal transition and metastasis. Cancer Res 71: 245-254, 2011

20. Eckert MA, Lwin TM, Chang AT, Kim J, Danis E, OhnoMachado L and Yang J: Twist1-induced invadopodia formation promotes tumor metastasis. Cancer Cell 19: 372-386, 2011.

21. Nieto MA: The snail superfamily of zinc-finger transcription factors. Nat Rev Mol Cell Biol 3: 155-166, 2002.

22. Barrallo-Gimeno A and Nieto MA: The Snail genes as inducers of cell movement and survival: Implications in development and cancer. Development 132: 3151-3161, 2005.

23. Hemavathy K, Guru SC, Harris J, Chen JD and Ip YT: Human Slug is a repressor that localizes to sites of active transcription. Mol Cell Biol 20: 5087-5095, 2000.

24. Wu WS, Heinrichs S, Xu D, Garrison SP, Zambetti GP, Adams JM and Look AT: Slug antagonizes p53-mediated apoptosis of hematopoietic progenitors by repressing puma. Cell 123: 641-653, 2005.

25. O'Bryan JP, Frye RA, Cogswell PC, Neubauer A, Kitch B, Prokop C, Espinosa R III, Le Beau MM, Earp HS and Liu ET: axl, a transforming gene isolated from primary human myeloid leukemia cells, encodes a novel receptor tyrosine kinase. Mol Cell Biol 11: 5016-5031, 1991.

26. Bose R, Molina H, Patterson AS, Bitok JK, Periaswamy B, Bader JS, Pandey A and Cole PA: Phosphoproteomic analysis of Her2/neu signaling and inhibition. Proc Natl Acad Sci USA 103 : 9773-9778, 2006.

27. Hafizi S and Dahlbäck B: Gas6 and protein S. Vitamin $\mathrm{K}$-dependent ligands for the Axl receptor tyrosine kinase subfamily. FEBS J 273: 5231-5244, 2006.

28. Duprey P and Paulin D: What can be learned from intermediate filament gene regulation in the mouse embryo. Int J Dev Biol 39: 443-457, 1995

29. Stewart M: Intermediate filament structure and assembly. Curr Opin Cell Biol 5: 3-11, 1993.

30. Takeda K and Akira S: STAT family of transcription factors in cytokine-mediated biological responses. Cytokine Growth Factor Rev 11: 199-207, 2000.

31. Manabe R, Oh-e N and Sekiguchi K: Alternatively spliced EDA segment regulates fibronectin-dependent cell cycle progression and mitogenic signal transduction. J Biol Chem 274: 5919-5924, 1999.

32. Ohnishi T, Hiraga S, Izumoto S, Matsumura H, Kanemura Y, Arita $\mathrm{N}$ and Hayakawa T: Role of fibronectin-stimulated tumor cell migration in glioma invasion in vivo: Clinical significance of fibronectin and fibronectin receptor expressed in human glioma tissues. Clin Exp Metastasis 16: 729-741, 1998.

33. Sakai T, Johnson KJ, Murozono M, Sakai K, Magnuson MA, Wieloch T, Cronberg T, Isshiki A, Erickson HP and Fässler R: Plasma fibronectin supports neuronal survival and reduces brain injury following transient focal cerebral ischemia but is not essential for skin-wound healing and hemostasis. Nat Med 7: 324-330, 2001
34. Moursi AM, Damsky CH, Lull J, Zimmerman D, Doty SB, Aota $\mathrm{S}$ and Globus RK: Fibronectin regulates calvarial osteoblast differentiation. J Cell Sci 109: 1369-1380, 1996.

35. Johansson S, Svineng G, Wennerberg K, Armulik A and Lohikangas L: Fibronectin-integrin interactions. Front Biosci 2: d126-d146, 1997.

36. Sottile $\mathrm{J}$ and Hocking DC: Fibronectin polymerization regulates the composition and stability of extracellular matrix fibrils and cell-matrix adhesions. Mol Biol Cell 13: 3546-3559, 2002.

37. Goerges AL and Nugent MA: pH regulates vascular endothelial growth factor binding to fibronectin: A mechanism for control of extracellular matrix storage and release. J Biol Chem 279: 2307-2315, 2004

38. Rao B, Lain S and Thompson AM: p53-Based cyclotherapy: Exploiting the 'guardian of the genome' to protect normal cells from cytotoxic therapy. Br J Cancer 109: 2954-2958, 2013.

39. Ma X, Liu L, Nie W, Li Y, Zhang B, Zhang J and Zhou R: Prognostic role of caveolin in breast cancer: A meta-analysis. Breast 22: 462-469, 2013.

40. Reed JC: Apoptosis mechanisms: Implications for cancer drug discovery. Oncology (Williston Park) 18 (Suppl 10): 11-20, 2004.

41. Cohen GM: Caspases: The executioners of apoptosis. Biochem J 326: 1-16, 1997.

42. Thornberry NA: Caspases: Key mediators of apoptosis. Chem Biol 5: R97-R103, 1998

43. Zheng TS, Hunot S, Kuida K and Flavell RA: Caspase knockouts: Matters of life and death. Cell Death Differ 6: 1043-1053, 1999.

44. Riedl SJ and Shi Y: Molecular mechanisms of caspase regulation during apoptosis. Nat Rev Mol Cell Biol 5: 897-907, 2004.

45. Zhou P, Jiang W, Weghorst CM and Weinstein IB: Overexpression of cyclin D1 enhances gene amplification. Cancer Res 56: 36-39, 1996.

46. Arnold A and Papanikolaou A: Cyclin D1 in breast cancer pathogenesis. J Clin Oncol 23: 4215-4224, 2005.

47. Kato J, Matsushime H, Hiebert SW, Ewen ME and Sherr CJ: Direct binding of cyclin $\mathrm{D}$ to the retinoblastoma gene product $(\mathrm{pRb})$ and $\mathrm{pRb}$ phosphorylation by the cyclin $\mathrm{D}$-dependent kinase CDK4. Genes Dev 7: 331-342, 1993.

48. Lundberg AS and Weinberg RA: Functional inactivation of the retinoblastoma protein requires sequential modification by at least two distinct cyclin-cdk complexes. Mol Cell Biol 18: 753-761, 1998.

49. Weinberg RA: The retinoblastoma protein and cell cycle control. Cell 81: 323-330, 1995.

50. Malumbres M and Barbacid M: To cycle or not to cycle: A critical decision in cancer. Nat Rev Cancer 1: 222-231, 2001.

51. Malumbres $\mathrm{M}$ and Barbacid $\mathrm{M}$ : Is Cyclin D1-CDK4 kinase a bona fide cancer target? Cancer Cell 9: 2-4, 2006.

52. Hayden MS and Ghosh S: Shared principles in NF-kappaB signaling. Cell 132: 344-362, 2008.

53. Hayden MS and Ghosh S: Signaling to NF-kappaB. Genes Dev 18: 2195-2224, 2004

54. Calaf GM and Hei TK: Establishment of a radiation- and estrogeninduced breast cancer model. Carcinogenesis 21: 769-776, 2000.

55. Soule HD, Maloney TM, Wolman SR, Peterson WD Jr, Brenz R, McGrath CM, Russo J, Pauley RJ, Jones RF and Brooks SC: Isolation and characterization of a spontaneously immortalized human breast epithelial cell line, MCF-10. Cancer Res 50: 6075-6086, 1990.

56. Calaf G, Russo J and Alvarado ME: Morphological phenotypes in neoplastic progression of benz(alpha)pyrene-treated breast epithelial cells. J Submicrosc Cytol Pathol 32: 535-545, 2000.

57. Calaf G, Russo J, Tait L, Estrad S and Alvarado ME: Morphological phenotypes in neoplastic progression of human breast epithelial cells. J Submicrosc Cytol Pathol 32: 83-96, 2000.

58. Calaf $\mathrm{G}$ and Hei TK: Oncoprotein expression in human breast epithelial cells transformed by high-LET radiation. Int J Radiat Biol 77: 31-40, 2001

59. Calaf GM, Alvarado ME and Hei TK: Beta catenin is associated with breast cancer progression in vitro. Int J Oncol 26: 913-921, 2005.

60. Calaf GM, Alvarado ME and Hei TK: Oncoprotein expression and morphological phenotypes of human breast epithelial cells transformed by the c-Ha-ras oncogene. Oncol Rep 14: 885-893, 2005.

61. Rodrigues CO, Nerlick ST, White EL, Cleveland JL and King ML: A Myc-Slug (Snail2)/Twist regulatory circuit directs vascular development. Development 135: 1903-1911, 2008. 
62. Hutterer M, Knyazev P, Abate A, Reschke M, Maier H, Stefanova N, Knyazeva T, Barbieri V, Reindl M, Muigg A, et al: Axl and growth arrest-specific gene 6 are frequently overexpressed in human gliomas and predict poor prognosis in patients with glioblastoma multiforme. Clin Cancer Res 14: 130-138, 2008

63. Li Y, Ye X, Tan C, Hongo JA, Zha J, Liu J, Kallop D, Ludlam MJ and Pei L: Axl as a potential therapeutic target in cancer: Role of Axl in tumor growth, metastasis and angiogenesis. Oncogene 28: 3442-3455, 2009.

64. Zhang YX, Knyazev PG, Cheburkin YV, Sharma K, Knyazev YP, Orfi L, Szabadkai I, Daub H, Kéri G and Ullrich A: AXL is a potential target for therapeutic intervention in breast cancer progression. Cancer Res 68: 1905-1915, 2008.

65. Wang S, Yu S, Shi W, Ge L, Yu X, Fan J and Zhang J: Curcumin inhibits the migration and invasion of mouse hepatoma Hca-F cells through down-regulating caveolin-1 expression and epidermal growth factor receptor signaling. IUBMB Life 63: 775-782, 2011.

66. Sun LN, Chen ZX, Liu XC, Liu HY, Guan GJ and Liu G: Curcumin ameliorates epithelial-to-mesenchymal transition of podocytes in vivo and in vitro via regulating caveolin-1. Biomed Pharmacother 68: 1079-1088, 2014.

67. Limtrakul P: Curcumin as chemosensitizer. Adv Exp Med Biol 595: 269-300, 2007.

68. Reuter S, Eifes S, Dicato M, Aggarwal BB and Diederich M: Modulation of anti-apoptotic and survival pathways by curcumin as a strategy to induce apoptosis in cancer cells. Biochem Pharmacol 76: 1340-1351, 2008.

69. Ruby AJ, Kuttan G, Babu KD, Rajasekharan KN and Kuttan R: Anti-tumour and antioxidant activity of natural curcuminoids Cancer Lett 94: 79-83, 1995.
70. Choudhuri T, Pal S, Das T and Sa G: Curcumin selectively induces apoptosis in deregulated cyclin D1-expressed cells at G2 phase of cell cycle in a p53-dependent manner. J Biol Chem 280: 20059-20068, 2005.

71. Salim LZ, Mohan S, Othman R, Abdelwahab SI, Kamalidehghan B, Sheikh BY and Ibrahim MY: Thymoquinone induces mitochondria-mediated apoptosis in acute lymphoblastic leukaemia in vitro. Molecules 18: 11219-11240, 2013.

72. Takaoka A, Hayakawa S, Yanai H, Stoiber D, Negishi H, Kikuchi H, Sasaki S, Imai K, Shibue T, Honda K, et al: Integration of interferon-alpha/beta signalling to $\mathrm{p} 53$ responses in tumour suppression and antiviral defence. Nature 424: 516-523, 2003.

73. Pekar O, Molotski N, Savion S, Fein A, Toder V and Torchinsky A: p53 regulates cyclophosphamide teratogenesis by controlling caspases 3, 8, 9 activation and NF-kappaB DNA binding. Reproduction 134: 379-388, 2007.

74. Fridman JS and Lowe SW: Control of apoptosis by p53. Oncogene 22: 9030-9040, 2003.

75. Aggarwal BB, Shishodia S, Takada Y, Banerjee S, Newman RA, Bueso-Ramos CE and Price JE: Curcumin suppresses the paclitaxel-induced nuclear factor-kappaB pathway in breast cancer cells and inhibits lung metastasis of human breast cancer in nude mice. Clin Cancer Res 11: 7490-7498, 2005.

76. Calaf GM, Echiburú-Chau C, Roy D, Chai Y, Wen G and Balajee AS: Protective role of curcumin in oxidative stress of breast cells. Oncol Rep 26: 1029-1035, 2011.

77. Huang T, Chen Z and Fang L: Curcumin inhibits LPS-induced EMT through downregulation of NF- $\kappa \mathrm{B}$-Snail signaling in breast cancer cells. Oncol Rep 29: 117-124, 2013. 